Олександр Володимирович Хоменко, аспірант відділу теорії держави і права Інституту держави і права ім. В.М. Корецького НАН Украӥни

\title{
МЕТОДОЛОГІЧНІ ПІДХОДИ ДОСЛІДЖЕННЯ ПРАВОВИХ ДЕФІНІЦІЙ: СУЧАСНИЙ КОНТЕКСТ
}

Постановка проблеми. Наукове осмислення будь-якого феномену передбачає насамперед правильне визначення методологічних засад його здійснення, які включають в себе не лише визначені прийоми, способи та засоби дослідження, а й систему поглядів, оцінок, образних уявлень про оточуючу соціальну дійсність та місце в ній людини, що обумовлює формування основних життєвих переконань, ідеалів та ціннісних орієнтацій відповідного суб'єкта.

Таким чином, у структурі методології загальнотеоретичної юридичної науки можна виокремити відповідні рівні, вищу ланку в системі яких, на нашу думку, займають не стільки, власне, методи дослідження як конкретні засоби і прийоми досягнення дослідницької мети, скільки концептуальний підхід (підходи), який визначає загальний напрям та стратегію дослідження, втілюючись у конкретній формі при застосуванні кожного методу.

Аналіз останніх досліджень та публікацій. Якщо звернутися до сучасного наукового доробку вітчизняних та зарубіжних вчених, то можна пересвідчитися, що проблематика методологічних підходів дослідження правових дефініцій вже була предметом доктринального осмислення, зокрема, таких вчених, як В. Бачинін, С. Бобровник, Р. Давид, В. Нерсесянц, Н. Оніщенко, Н. Пархоменко, О. Петришин, Т. Подорожна, А. Поляков, С. Шевчук, Ю. Шемшученко, О. Ющик тощо. Втім, реалії сьогодення переконливо доводять необхідність переосмислення системи концептуальних підходів дослідження правових дефініцій, зокрема, з метою підвищення ефективності їх застосування у юридичній практиці.

Мета статті. Метою цієї статті є загальнотеоретичне осмислення основних методологічних підходів дослідження правових дефініцій та визначення перспектив їх подальшого розвитку.

Основні результати дослідження. У сучасній юридичній літературі наголошується, що підхід по відношенню до методу є більш високим рівнем у структурі методології, а тому передбачає застосування, як правило, декількох методів, що пов'язані зі стратегією наукового дослідження. При цьому в основу наукових підходів дослідження покладається концептуальна ідея, що безпосередньо визначає спрямованість та впливає на інтерпретацію його результатів. У такий спосіб науковий підхід являє собою органічне поєднання світоглядно-філософської спрямованості з методичним інструментарієм, що використовується в певній галузі дослідження [1, с. 57].

Отже, спробуємо осмислити методологію дослідження правових дефініцій в контексті загальнотеоретичної юриспруденції, виокремивши насамперед концептуальні підходи до пізнання та осмислення права як особливого нормативного феномену соціальної дійсності, які мають певну філософсько-світоглядну основу.

Якщо звернутися до аналізу сучасної наукової літератури, присвяченої різноманітним проблемам дослідження правових дефініцій, то можна пересвідчитися у наявності різних точок зору на розуміння їх природи, особливостей формування, функціональну спрямованість тощо. Водночас, переважну більшість підходів до розуміння правових дефініцій можна умовно об'єднати у три основні групи, а саме:

1. Представники першої групи, досліджуючи природу правових дефініцій, акцентують увагу на змістовній складовій відповідного поняття, яке розкривається через відповідну дефініцію шляхом здійснення інтелектуальної, логічної операції, що надає можливість встановити його суттєві характеристики або ознаки. У такий спосіб правова дефініція визначається, зокрема, як «припис, що розкриває зміст правового поняття шляхом вказівки його основних юридично значущих ознак або елементів з метою забезпечення єдності правового регулювання» [2, с. 22], або як «стисле визначення певного поняття, яке відображає суттєві (якісні) ознаки правового явища» [3, с. 182]. 
Основу формально-логічного підходу дослідження правових дефініцій складають відповідні логічні правила їх формулювання, серед яких, зокрема, вимога відсутності тавтології та заперечення у визначенні, вимога несуперечливості та лаконічності дефініції тощо. Як бачимо, формально-логічний підхід у дослідженні правових дефініцій спрямований на належну організацію їх змістовного насичення, хоча очевидним, на нашу думку, є також і те, що зміст правових дефініцій конституюється не лише за допомогою правил формальної логіки і включає в себе щонайменше певні ціннісно-світоглядні засади та орієнтації, втілені у відповідних філософських категоріях.

2. Представники другої групи дослідників вбачають основу будь-яких дефініцій, у тому числі правових, у їх мовному виразі, тобто вони вивчають їх зміст з точки зору лінгвістичних операцій або позицій, як певне розташування слів та розділових знаків між ними. Так, у свій час англійський філософ Дж. Локк стверджував, що «надати визначення - означає лише надати іншому зрозуміти за допомогою слів, яку ідею позначає визначений термін» [4, с. 470]. Л. Вітгенштейн також вважав, що основу визначень складають мовні правила, у тому числі правила перекладу з однієї мови на іншу [5, с. 43$]$.

Мова права - це його своєрідна матеріальна оболонка, його іманентна форма, яка втілює його зміст. Права без мови немає і бути не може. У зв'язку з цим, під правовою дефініцією цілком обгрунтовано можна розуміти один із найважливіших засобів, що забезпечує ясність, однозначність і визначеність понять, які вживаються, зокрема, і в законодавстві [6, с. 13, 17; 7, с. 5].

Як слушно вважають окремі вітчизняні вчені у галузі кримінального права, проблематика термінології права й законодавства, безсумнівно, належить до найбільш актуальних, оскільки від їхнього правильного рішення залежить не тільки розв'язання теоретичних дилем, а й вирішення багатьох питань правозастосування, тобто фактично долі конкретних людей. Визначальною при цьому є роль дослідження термінологічних проблем теорії й практики кримінального права, оскільки саме в цій галузі ціна слова, а іноді навіть букви або розділового знака, надзвичайно висока [8, с. 3; 9, с. 57-61].

3. Представники третьої групи підходів до дослідження правових дефініцій вивчають останні, як правило, з точки зору поєднання в них одночасно логічних та лінгвістичних складових. Зокрема, К. Панько вважає, що правові дефініції потрібно досліджувати одночасно як спосіб структурування, упорядкування основних ознак відповідних понять, спосіб виявлення їх змісту, а також як знакову систему їх оформлення [10, с. 104]. Т. Губаєва при визначенні правових дефініцій також наголошує на поєднанні логічних та лінгвістичних складових відповідного поняття, розуміючи під правовою дефініцією загальну словесну формулу, в якій об'єднані всі суттєві ознаки певного поняття [11, с. 70-71].

Віддаючи належне кожному із запропонованих підходів, які превалюють у сучасній науковій літературі, вважаємо за доцільне зауважити, що розуміння природи правових дефініцій не може обмежуватися лише формально-логічним та лінгвістичним підходами, що пов'язано насамперед з соціальним виміром права як унікального нормативного феномену людської цивілізації. Саме тому дослідження правових дефініцій повинно спиратися на відповідну систему підходів та методів дослідження, які, окрім заявлених вище, включають в себе також філософський (метафізичний та діалектичний), соціологічний, аксіологічний, герменевтичний, культурологічний та інші підходи їх пізнання і вивчення.

Погоджуючись загалом 3 тим, що право взагалі та правові дефініції зокрема не можуть існувати поза логіко-лінгвістичним полем свого формулювання, осмислення та інтерпретації, все ж ïх внутрішня (змістовна) та зовнішня (мовна) форми не можуть не нести на собі певний відбиток світоглядних, економічних, політичних, національних, духовних, історичних, психологічних та інших чинників. Доктринальні розробки проблем логіки права та юридичної лінгвістики, звичайно, заслуговують на належну увагу, але вони не здатні замінити або підмінити собою цілісний, багатоаспектний характер соціального виміру права, за допомогою якого, серед іншого, пояснюються взаємозв'язок та взаємозалежність всіх правових понять, виражених у відповідних термінах та їх дефініціях.

У зв'язку із зазначеним вважаємо, що наукове осмислення відповідних явищ або феноменів соціальної дійсності, у тому числі правових, повинно починатися насамперед з визначених світоглядних, фундаментальних ідей та положень, зміст яких представлений у вигляді філософських парадигм та принципів наукового пізнання. Зокрема, надзвичайно важливе методологічне значення у дослідженні правових дефініцій відіграють діалектичний, метафізичний та інші філософські підходи, які визначають загальний напрям та стратегію їх осмислення. 
Так, метафізика як один із загальних філософсько-світоглядних підходів до осмислення феноменів соціальної дійсності передбачає дослідження відповідних об’єктів у їх незмінному, статичному стані, визначаючи їх фундаментальні трансцендентні характеристики, їх ціннісно-смислову субстанціональність. Як вірно зауважують окремі вітчизняні науковці, метафізичний підхід надає можливість бачити в нормах та цінностях права символи «надособистісних енергій, що беруть участь у творенні соціального світу та земного правопорядку». Даний підхід припускає, що через правові норми та цінності людина у певній мірі прилучається до вищих, абсолютних гармоній буття, у світлі яких соціальний правопорядок - це лише їх «приватна, локальна форма». Норми та цінності права, у такий спосіб, об’єднують в собі «метафізичний світ абсолютної повинності і соціальний світ сущого». Адже кожна правова норма органічно поєднує в собі як абсолютне імперативне начало, так і реальну модель поведінки, в якій лише частково та обмежено реалізується вищий імператив [12, с. 193-194].

Відтак, за допомогою метафізичного підходу правові дефініції осмислюються не лише з точки зору їх раціонально-логічного пояснення та обгрунтування, прив'язки до конкретної емпіричної та відносної ситуації, а у контексті фундаментальних ціннісно-духовних засад їх формування, здатних задавати ідеальний, трансцендентний стандарт їх телеологічного виміру. Метафізика надає можливість осмислювати та пізнавати правові дефініції з точки зору духовних першооснов буття, відображених або невідображених у їх змісті; з точки зору цілісності соціонормативної регуляції тощо. Поза контекстом вказаного підходу неможливо успішно досліджувати правові дефініції, змістовна насиченість яких прив'язана до метанормативного рівня (наприклад, такі правові дефініції, як шлюб, законний інтерес, правопорушення та злочин, суспільна мораль, свобода совісті, право власності, свобода думки і слова тощо). Вивчення цих та багатьох інших правових дефініцій лише за допомогою відносних та емпіричних засобів, які акумулюються, зокрема, у соціологічному, історичному та інших методологічних підходах, не розкриватиме всіє повноти та цілісності їх змісту, за допомогою чого можна наблизитися до осягнення сутності тієї соціально-правової дійсності, в якій живе конкретна людина. Саме метафізичний підхід здатний ефективно стримувати напругу проблемного поля соціальних антиномій, тобто протиріч між двома положеннями, які внаслідок різних причин визнаються однаково вірними, а також належним чином сприяти подоланню відповідних колізій між правовими дефініціями, формуючи тим самим більш стабільні критерії ïx істинності та системно пояснюючи складність всього механізму їх соціокультурної детермінації.

Поряд з метафізичним підходом, надзвичайно важливе значення у дослідженні правових дефініцій відіграє також діалектичний підхід, який виходить з постійної змінюваності та розвитку відповідних соціальних та природних феноменів, джерелом якої є визнається насамперед внутрішня суперечливість, боротьба та взаємозв'язок між ними.

У науковій літературі відзначається, що діалектичний підхід у дослідженні, зокрема, правових понять та категорій передбачає їх розгляд у якості складних та взаємопов'язаних логіко-гносеологічних конструкцій, об'єктивованих у певній внутрішній структурі, змісті, сутності, функціях, взаємозв'язках із явищами і процесами, які утворюють конкретно-історичне середовище їх формування та розвитку [13, с. 30-31]. Діалектичний підхід передбачає необхідність всебічного вивчення держави і права як явищ, що знаходяться в динаміці та постійному оновленні, як феноменів, пов'язаних з іншими соціальними чинниками - економікою, політикою, духовною сферами тощо. 3 цією метою загальна теорія держави і права має пов'язувати свої висновки 3 досягненнями всіх соціогуманітарних та юридичних наук. Дослідження державно-правової дійсності значною мірою спрямовується такими загальними категоріями діалектики, як сутність і явище, форма і зміст, можливість і дійсність. На цій основі сама юридична наука повинна постійно поглиблювати знання про державу і право, переходити від емпіричного до теоретичного рівня, що є проявом діалектичної ідеї безперервного руху в природі, суспільстві та мисленні [14, с. 28].

Отже, можемо стверджувати, що використання діалектичного підходу у дослідженні правових дефініцій надає можливість: 1) по-перше, вивчати та осмислювати правові дефініції як факт складної та суперечливої соціальної дійсності, а не з точки зору певного заздалегідь заданого ідеального стандарту; 2) по-друге, розглядати правові дефініції з точки зору взаємообумовленості та взаємозв' язку їх змісту та форми; 3) по-трете, виявляти соціальні чинники, які впливають на становлення та розвиток правових дефініцій в межах визначених темпорально-просторових вимірів; 4) по-четверте, удосконалювати процеси гармонізації та уніфікації правових дефініцій, що набуває 
особливої актуальності в умовах правової акультурації та глобалізації; 5) по-п'яте, спрогнозувати характер поступових змін правових дефініцій як за змістом, так і за формою.

Окрім метафізичного та діалектичного підходів, важливу роль у методології дослідження державно-правових явищ взагалі та правових дефініцій зокрема відіграють також соціологічний, герменевтичний, культурологічний, аксіологічний та інші загальнонаукові, філософські підходи.

Зокрема, вагому роль у дослідженні правових дефініцій відграє також соціологічний підхід, який надає можливість враховувати взаємозв'язок конкретного соціального середовища та права, яке функціонує в його межах. Соціологічний підхід у правознавстві поєднує в собі насамперед дві групи методів: методи збору правової інформації та методи обробки отриманої інформації. До першої групи методів належать опитування, анкетування, інтерв'ювання, спостереження, соціального експерименту, а до другої - методи аналізу документів, вибірковий метод, метод вивчення статистичних даних тощо. Застосування цього підходу передбачає необхідність забезпечення надійності отриманих емпіричних даних, репрезентативності і точності соціологічної інформації, що досягається передусім за рахунок вибіркового методу [15, с. 41].

У зазначеному контексті слід відзначити, що якісну основу процесу формування правових дефініцій складає належним чином здійснений збір та обробка теоретичних і емпіричних даних правового життя суспільства, узагальнення матеріалів юридичної практики, офіційних та неофіційних правових документів, експертних правових висновків тощо. Особливу значущість збір і обробка вказаної інформації набувають в процесі підготовки проектів нормативно-правових актів та формуванні джерел правозастосовної, зокрема, судової практики. Адже переважна більшість цих актів містить відповідні правові дефініції, які підлягають застосуванню при вирішення конкретних практичних ситуацій та справ, і адекватність змісту цих дефініцій в межах конкретної соціальної реальності безпосередньо залежить від ступеня врахування соціологічних емпіричних даних.

Крім цього, не можна також не враховувати і той факт, що застосування правових дефініцій в процесі вирішення тих чи інших практичних ситуацій об'єктивно вимагає від відповідного суб'єкта здійснення належного, обгрунтованого тлумачення або інтерпретації їх змісту. Таке тлумачення або інтерпретація правових дефініцій, а по суті - особливого правового тексту - забезпечується за допомогою герменевтичного підходу у правознавстві, який зорієнтований на розробку засобів розуміння і тлумачення змісту правових норм, виражених у певній формі.

У науковій літературі справедливо відзначається, що герменевтика - особливий методологічний інструментарій, використовуючи який можна зрозуміти та розтлумачити не лише сам текст, а й до певної міри пізнати автора тексту, зокрема, законодавця, людину, суспільство тощо. Герменевтичний спосіб розуміння і тлумачення соціальної, у тому числі правової дійсності, заснований на проникненні не лише у зовнішньо виражений (об'єктивний) світ, але й у суб'єктивний також, оскільки тлумачення здійснюється як з урахуванням суб'єктивних позицій самого інтерпретатора, так і індивідуальних особливостей мови автора [16, с. 68].

Очевидно, що розуміння правових дефініцій передбачає привнесення суб'єктом до сформульованих раціональних моделей розуміння тих чи інших понять і категорій своїх особистих, суто індивідуальних акцентів. При цьому зрозуміло, що таке «привнесення індивідуальності» в процесі осмислення змісту правових дефініцій повинно відбуватися з урахуванням відповідних принципів та вимог, у разі недотримання яких воно матиме свавільний характер, який унеможливить або принаймні суттєво ускладнить законне та справедливе вирішення конкретної ситуації. Адже у світлі герменевтичного підходу правові дефініції відображають не лише певні знання про ті чи інші важливі соціальні явища і процеси, які вимагають правового оформлення, а й суб'єктивно-особистісну оцінку їх осмислення та розуміння. Саме тому особливу значущість у сфері юридичної герменевтики набуває питання меж інтерпретаційної свободи суб'єкта тлумачення.

Важливого значення у процесі дослідження правових дефініцій набувають також культурологічний та аксіологічний підходи. Основу культурологічного підходу до права складає теза, згідно із якою правові явища відбивають у своєму змісті, окрім, власне, суто юридичного компоненту, ще й смисли та цінності позаюридичного характеру, а точніше - цілісного історико-культурного досвіду відповідного суспільства або навіть певної цивілізації. Даний підхід до права надає можливість розглядати будь-який правовий феномен не автономно, а у контексті численних взаємозв'язків в межах реального простору культурних символів, цінностей та смислів. Культурологічний підхід до права передбачає необхідність врахування низки культурних детермінант пра- 
вового розвитку і спрямований на подолання жорсткого позитивізму та догматизму в осмисленні правових феноменів. У контексті культурологічного підходу індивід як суб'єкт правосвідомості та правовідносин стає духовно-автономною особистістю, який має креативні здібності, здатен свідомо та відповідально приймати рішення, не перекладаючи відповідальність на зовнішні обставини чи інших суб'єктів [17, с. 466].

3 огляду на зазначене, можемо констатувати, що в складних та суперечливих реаліях сьогодення необхідність застосування культурологічного підходу при дослідженні правових дефініцій суттєво зростає. На нашу думку, однією з основних причин, які обумовлюють необхідність та доцільність застосування культурологічного підходу до осмислення правових дефініцій, є посилення процесів демократизації та лібералізації суспільного і державного життя, а відтак і розширення меж індивідуальних прав і свобод, внаслідок чого виникає необхідність у встановленні чітких ціннісно-смислових орієнтирів їх реалізації в конкретному суспільстві. Такі орієнтири можуть бути встановлені та сприйняті суспільством лише тоді, коли правова реальність взагалі та правові дефініції зокрема осмислюються через культурологічний підхід, тобто через цілісну соціонормативну традицію відповідного суспільства, особливості його менталітету тощо. Адже правові поняття та їх дефініції завжди так чи інакше прив’язуються до конкретного соціокультурного виміру, до цілісної соціонормативної традиції стандартизації суспільного життя та міжособистісної комунікації, до певного досвіду соціальної практики тощо. При цьому особливу значущість культурологічний підхід має при формулюванні законодавчих дефініцій у тих випадках, коли відповідне поняття 3 огляду на визначену культурологічну традицію має системний соціонормативний вимір свого осмислення та розуміння в суспільстві, нехтування яким може призвести до посилення або загострення соціальних протиріч.

Поряд із культурологічним підходом, важливе значення у дослідженні правових феноменів відіграє також і аксіологічний підхід, який вивчає право крізь призму його співвіднесеності 3 певними цінностями, що можуть забезпечуватися правом та одночасно бути його основою [18, с. 63]. Основу аксіологічного підходу у праві, на нашу думку, складає не стільки факт визнання людини найвищою соціальною цінністю, скільки приреченість особистості на здійснення постійного вибору певного рішення серед визначеної сукупності варіантів, що опосередковується ії різноманітними ціннісними орієнтаціями.

Слід відзначити, що право як особлива соціонормативна система завжди закріплює, охороняє та захищає певну систему цінностей, зміст яких, як правило, виходить за межі правової матерії. Зокрема, правові норми, у тому числі норми-дефініції, прямо або опосередковано закріплюють у своєму змісті такі цінності, як права і свободи людини, демократія, прогрес, особисте благо, справедливість, добросовісність, розумність, власність, рівність, гуманізм тощо. При цьому потрібно наголосити, що переважна більшість цінностей, закріплених у праві, не є суто правовими за своїм характером, оскільки їх зміст долучається до всього контексту ціннісно-смислової матриці відповідної культури. Саме тому про окремі або так звані «приватні» правові цінності можна вести мову лише умовно, оскільки вони по суті є лише юридичною формою більш значущих, універсальних цінностей [19, с. 14], яка є необхідною з огляду на недосконалість людської природи та необхідність у зв'язку із цим встановлення додаткових гарантій забезпечення розумності та соціальної корисності індивідуального людського вибору.

Застосування аксіологічного підходу в процесі дослідження правових дефініцій надає можливість визначати, конкретизувати їх смисловий контекст, з'ясувати зміст загальнозначущого ядра ідей та принципів, покладених в основу таких дефініцій, виявити ієрархічну структуру таких цінностей, глибинний цивілізаційно-культурний контекст їх змісту, а не лише догму права.

Висновки. 3 огляду на все вищенаведене, можемо зробити наступні висновки:

1. Основу методології дослідження правових дефініцій в контексті загальнотеоретичної юриспруденції складає система взаємопов'язаних підходів, які повинні включати в себе не лише формально-логічні та лінгвістичні прийоми їх наукового осмислення, а й визначений філософсько-світоглядний та соціологічний вимір, виражений, зокрема, у метафізичному, діалектичному, герменевтичному, культурологічному та аксіологічному підходах.

2. Система запропонованих методологічних підходів дослідження правових дефініцій надає можливість зосередити увагу не лише на їх зовнішніх параметрах, виражених у відповідних формальних ознаках певних понять, зміст яких розкриває дефініція, але й осягнути їх глибинний цін- 
нісно-смисловий контекст, в межах якого поєднуються духовні першооснови буття та раціонально-емпірична складова їх конкретного соціокультурного прояву.

3. Одним із перспективних напрямів подальшого розвитку методології дослідження правових дефініцій слід визнати посилення принципу системності їх осмислення, що передбачає, зокрема, їх розгляд у контексті визначених взаємозв'язків з іншими соціальними, правовими явищами.

\section{Список використаних джерел}

1. Фальковський А. О. Підходи в сфері посткласичної методології юриспруденції // Право і суспільство. - 2015. № 5. - C. 54-59.

2. Дачковська О. Правові дефініції як різновид нормативних приписів // Вісник Національної академії правових наук України. - 2012. - № 3. - С. 16-23.

3. Каманина Т. В. Юридическая техника : учеб. - 2-е изд., пересмотр. - М. : Норма: ИНФРА-М, 2011. - 496 с.

4. Локк Д. Опыт о человеческом разумении // Сочинения в 3-х т. : Т. 1 / Ред. : И. С. Нарский, А. Л. Субботин; Ред. І т., авт. вступит. статьи и примеч. И. С. Нарский; Пер. с англ. А. Н. Савина. - М. : Мысль, 1985. - С. 78-582.

5. Витгенштейн Л. Логико-философский трактат / Пер. с нем.; общ. ред. и предисл. : В. Ф. Асмус. - М. : Наука, 1958. $-133 \mathrm{c}$.

6. Подорожна Т. С. Законодавчі дефініції: поняття, структура, функції : моногр. - Львів : ПАІС, 2009. - 196 с.

7. Семенюк Э. П. Общенаучные категории и подходы к познанию. Философский анализ. - Львов : Вища школа, 1978. $-174 \mathrm{c}$.

8. Тростюк 3. Понятійний апарат Особливої частини Кримінального кодексу України : моногр. - К. : Атіка, 2003. $-144 \mathrm{c}$.

9. Кочан I. M. Юридична термінологія крізь призму лінгвістики // Науковий вісник Міжнародного гуманітарного університету. Серія: Філологія. - 2018. - № 32; Т. 3. - С. 57-61.

10. Панько K. К. Теория и практика законотворчества в уголовном праве : моногр. - М. : Юрлитинформ, 2011. $312 \mathrm{c}$.

11. Губаева Т. В. Язык и право. Искусство владения словом в профессиональной юридической деятельности. 2-е изд., пересмотр. - М. : Норма: Инфра-М, 2010. - 176 с.

12. Бачинін В. А., Журавський В. С., Панов М. І. Філософія права : словник. - К. : Концерн «Видавничий Дім «ІІ Юре», 2003. -408 c.

13. Іваненко $О$. Специфіка використання категорій і законів діалектики під час дослідження явищ державноправової дійсності // Jurnalul Juridic National: Teorie si Practica. - 2015. - № 6. - C. 29-32.

14. Загальна теорія держави і права : підруч. для студентів юридичних вищих навчальних закладів / М. В. Цвік, О. В. Петришин, Л. В. Авраменко та ін. / За ред. М. В. Цвіка та О. В. Петришина. - Харків : Право, 2010. $584 \mathrm{c}$.

15. Кельман М. Методологія сучасного правознавства: становлення та основні напрями розвитку // Психологія і суспільство. - 2015. - № 4. - С. 33-46.

16. Карващька С. Б. Формування герменевтичної інтерпретації: історико-правові та лінгвістичні питання // Актуальні проблеми держави і права: зб. наук. пр. - 2009. - Вип. 50. - С. 66-72.

17. Бачинин В. А. Энциклопедия философии и социологии права. - СПб : Издательство Р. Асланова «Юридический центр Пресс», 2006. -1093 с.

18. Фальковський $A$. О. До визначення поняття аксіологічного дослідницького підходу в методології юриспруденції // Актуальні проблеми держави і права: зб. наук. пр. - 2008. - Вип. 40. - С. 59-64.

19. Мартытшин О. В. Проблема ценностей в теории государства и права // Государство и право. - 2004. - № 10. C. 5-14.

\section{References}

1. Falkovskyi A. O. Pidkhody v sferi postklasychnoi metodolohii yurysprudentsii // Pravo i suspilstvo. - 2015. - № 5. S. 54-59.

2. Dashkovska $O$. Pravovi definitsii yak riznovyd normatyvnykh prypysiv // Visnyk Natsionalnoi akademii pravovykh nauk Ukrainy. - 2012. - № 3. - S. 16-23.

3. Kashanina T. V. Yuridicheskaya tekhnika: uchebnik. - 2-e izd., peresmotr. - M. : Norma: INFRA-M, 2011. - $496 \mathrm{~s}$.

4. Lokk D. Opyt o chelovecheskom razumenii // Sochineniya v 3-h t.: T. 1 / Red. : I. S. Narskij, A. L. Subbotin; Red. I t., avt. vstupit. stat'i i primech. I. S. Narskij; Per. s angl. A. N. Savina. - M. : Mysl', 1985. - S. 78-582.

5. Vitgenshtejn L. Logiko-filosofskij traktat / Per. s nem.; obshch. red. i predisl.: V. F. Asmus. - M. : Nauka, 1958. - $133 \mathrm{~s}$.

6. Podorozhna T. S. Zakonodavchi definitsii: poniattia, struktura, funktsii : monohrafiia. - Lviv: PAIS, 2009. - $196 \mathrm{~s}$.

7. Semenyuk E. P. Obshchenauchnye kategorii i podhody k poznaniyu. Filosofskij analiz. - L'vov : Vishcha shkola, 1978. $-174 \mathrm{~s}$. 
8. Trostiuk Z. Poniatiinyi aparat Osoblyvoi chastyny Kryminalnoho kodeksu Ukrainy: monohrafiia. - K. : Atika, 2003. $144 \mathrm{~s}$.

9. Kochan I. M. Yurydychna terminolohiia kriz pryzmu linhvistyky // Naukovyi visnyk Mizhnarodnoho humanitarnoho universytetu. Seriia: Filolohiia. - 2018. - № 32; T. 3. - S. 57-61.

10. Pan 'ko K. K. Teoriya i praktika zakonotvorchestva v ugolovnom prave: monografiya. - M. : Yurlitinform, $2011 .-312 \mathrm{~s}$.

11. Gubaeva T. V. Yazyk i pravo. Iskusstvo vladeniya slovom v professional'noj yuridicheskoj deyatel'nosti. - 2-e izd., peresmotr. - M. : Norma: Infra-M, 2010. - 176 s.

12. Bachynin V. A., Zhuravskyi V. S., Panov M. I. Filosofiia prava: slovnyk. - K. : Kontsern «Vydavnychyi Dim «In Yure», 2003. $-408 \mathrm{~s}$.

13. Ivanenko $O$. Spetsyfika vykorystannia katehorii i zakoniv dialektyky pid chas doslidzhennia yavyshch derzhavnopravovoi diisnosti // Jurnalul Juridic National: Teorie si Practica. - 2015. - № 6. - S. 29-32.

14. Zahalna teoriia derzhavy i prava: Pidruchnyk dlia studentiv yurydychnykh vyshchykh navchalnykh zakladiv / M. V. Tsvik, O. V. Petryshyn, L. V. Avramenko ta in. / Za red. M. V. Tsvika ta O. V. Petryshyna. - Kharkiv : Pravo, 2010. $584 \mathrm{~s}$.

15. Kelman M. Metodolohiia suchasnoho pravoznavstva: stanovlennia ta osnovni napriamy rozvytku // Psykholohiia i suspilstvo. - 2015. - № 4. - S. 33-46.

16. Karvatska $S$. B. Formuvannia hermenevtychnoi interpretatsii: istoryko-pravovi ta linhvistychni pytannia // Aktualni problemy derzhavy i prava: zb. nauk. pr. - 2009. - Vyp. 50. - S. 66-72.

17. Bachinin V. A. Enciklopediya filosofii i sociologii prava. - SPb : Izdatel'stvo R. Aslanova «Yuridicheskij centr Press», 2006. - $1093 \mathrm{~s}$.

18. Falkovskyi A. O. Do vyznachennia poniattia aksiolohichnoho doslidnytskoho pidkhodu v metodolohii yurysprudentsii// Aktualni problemy derzhavy i prava : zb. nauk. pr. - 2008. - Vyp. 40. - S. 59-64.

19. Martyshin O. V. Problema cennostej v teorii gosudarstva i prava // Gosudarstvo i pravo. - 2004. - № 10. - S. 5-14.

\section{Хоменко О. В. Методологічні підходи дослідження правових дефініцій: сучасний контекст}

Стаття присвячена огляду проблематики сучасних методологічних підходів дослідження правових дефініцій. Наголошується, що науковий підхід, у порівнянні із методом, перебуває на більш високому рівні у структурі методології, оскільки пов'язаний зі стратегією наукового дослідження. Робиться висновок, що система методологічних підходів дослідження правових дефініцій повинна включати в себе, зокрема, ті з них, за допомогою яких можна осягнути їх глибинний ціннісно-смисловий контекст.

Ключові слова: методологія, методологічний підхід, метод, правові дефініції, право, цінність, поняття.

\section{Khomenko O. V. Methodological approaches to the study of law definitions: contemporary context}

The article is devoted to the review of the problems of modern methodological approaches to the study of law definitions. It is noted that understanding of the nature of law definitions cannot be limited to formal-logical and linguistic approaches, which is primarily related to the social dimension of law as the unique normative phenomenon of human civilization. That is why the study of law definitions should be based on the appropriate system of approaches and research methods, which, in addition to the above, also include philosophical (metaphysical and dialectical), sociological, axiological, hermeneutical, historical and other approaches to their knowledge and study.

In particular, with the help of a metaphysical approach law definitions are interpreted not only from the point of view of their rationally-logical explanation and justification, binding to a particular empirical and relative situation, but in the context of the fundamental value-and-spiritual principles of their formation, capable of setting the ideal, transcendental standard of their teleological measurement. Outside the context of this approach it is impossible to successfully investigate law definitions, the content saturation of which is tied to the metanormative level (for example, such law definitions as marriage, lawful interest, offense and crime, public morality, freedom of conscience, property rights, freedom of thought and speech, etc.).

The use of the dialectical approach in the study of law definitions provides an opportunity: 1) first, to study and comprehend law definitions as a fact of complex and contradictory social reality, and not from the point of view of a predetermined ideal standard; 2) secondly, to consider law definitions in terms of the interdependence and the interrelation between their content and form; 3 ) third, to identify social factors that influence the formation and development of law definitions within the defined temporal-spatial dimensions; 4) fourthly, to improve the processes of harmonization and unification of law definitions, which becomes especially relevant in the conditions of law acculturation and globalization; 5) fifth, to predict the nature of the gradual changes in law definitions both in terms of content and form.

In addition, we cannot ignore the fact that the use of law definitions in the process of solving certain practical situations objectively requires the relevant subject to exercise an appropriate, reasoned explanation or interpretation of their content. Such an explanation or interpretation of law definitions, and in essence - a special law text - is provided by means of a hermeneutic approach in jurisprudence, which focuses on the development of means for understanding and interpreting the content of legal norms expressed in a certain form. 
Also it is noted, that cultural and axiological approaches also play an important role in the process of studying law definitions.

In conclusion it is summed up that the system of proposed methodological approaches to the study of law definitions provides an opportunity to focus an attention not only on their external parameters, expressed in the corresponding formal features of certain concepts, the content of which reveals the definition, but also to comprehend their deep value-semantic context, within which the spiritual foundations of being and the rational-empirical component of their particular sociocultural manifestation are combined.

Key words: methodology, methodological approach, method, law definitions, law, value, concept.

DOI: 10.33.66.3/2524-017X-2019-10-341-348

УДК 340.1

Тетяна Олексіӥвна Чепульченко, кандидат юридичних наук, завідувач кафедри публічного права факультету сочіології і права ННТУ «КПІ» ім. Ігоря Сікорського

\section{ПРАВА ЛЮДИНИ ЯК МЕТА І МЕЖІ ПРАВОТВОРЧОСТІ}

Постановка проблеми. Безсистемність, якою іноді характеризується правотворча діяльність, пов'язується з відсутністю чіткого уявлення про правову урегульованість тих чи інших суспільних відносин. На заваді ефективного регулювання суспільних відносин стоять чимало факторів, серед яких правові колізії і прогалини, невідповідність нормативно-правових приписів реальним потребам і очікуванням громадян і т. і. Для подолання вказаного необхідним $є$ постійне вивчення динамічного законодавства, контроль за цими змінами та відповідністю їх реальним умовам життя суспільства, особливо правам та свободам людини.

Для досягнення мети правотворчості необхідно виявити потребу в правовому регулюванні, вивчити фактори, які визначають його напрямок та які вказують на загальні очікування учасників суспільних відносин.

Зокрема, слід звернути увагу на відсутність чітких уявлень про стан усього законодавчого масиву, формально діючого в Україні. При цьому слід враховувати, що йдеться не тільки про існування чи відсутність закону з того чи іншого питання, а передусім про його відповідність сьогоднішнім умовам та поставленій меті, яка має принести соціально корисний результат, а також слугувати якісному забезпеченню та захисту основних прав людини. Адже відповідно до положень ст. 3 Конституції України: «Людина, іiі життя і здоров’я, честь і гідність, недоторканність і безпека визнаються в Україні найвищою соціальною цінністю. Права і свободи людини та їх гарантії визначають зміст і спрямованість діяльності держави. Держава відповідає перед людиною за свою діяльність. Утвердження і забезпечення прав і свобод людини $є$ основним обов'язком держави».

У зв'язку з цим особливо слід наголосити на необхідності врахування наукового обгрунтування термінів та категорій, які застосовуються суб'єктами правотворчості. Практика показує, що не завжди стрімкі правотворчі процеси у державі зважають на принцип науковості та інші важливі принципи, що породжує неоднозначне розуміння правових приписів і, відповідно, порушення основоположних прав і свобод.

Аналіз останніх досліджень та публікацій. Про потребу досліджень у цій сфері вже неодноразово наголошували такі українські фахівці в галузі теорії держави і права, як А Заєць, О. Зайчук, М. Козюбра, А. Колодій, М. Цвік, Ю. Оборотов, Н. Оніщенко, М. Погребняк, П. Рабінович, В. Селіванов, О. Скакун, О. Скрипнюк, С. Шевчук та ін.

Зокрема, значна увага приділена вивченню соціальних аспектів правотворення, його принципам та видам, нормотворчій діяльності та проблемам систематизації законодавства, етичній культурі юристів тощо такими правознавцями, як М. Баймуратов, С. Бобровник, Ж. Дзейко, Н. Железняк, 